\title{
Manajemen kesiswaan terhadap hasil belajar
}

\author{
Mutia Putri $^{\left.{ }^{*}\right)}$, M. Giatman ${ }^{1}$, Ernawati Ernawati ${ }^{1}$ \\ ${ }^{1}$ Universitas Negeri Padang
}

\begin{tabular}{l}
\hline Article Info \\
\hline Article history: \\
Received May $07^{\text {th }}, 2021$ \\
Revised Jun $25^{\text {th }}, 2021$ \\
Accepted Jul $12^{\text {th }}, 2021$ \\
\hline
\end{tabular}

\section{Keyword:}

Manajemen

Kesiswaan

Hasil belajar

\begin{abstract}
Tujuan dari penelitian ini adalah untuk mendeskripsikan pengaruh manajemen kesiswaan terhadap hasil belajar peserta didik. Manajemen kesiswaan inilah yang khusus berkaitan dengan penentuan bentuk dari bimbingan siswa dalam belajar. Penelitian ini menerapkan metode kajian pustaka dan dalam pengumpulan data penelitian me-review artikel-artikel. Dari hasil penelitian yang dilakukan diketahui bahwa manajemen kesiswaan sangat berpengaruh terhadap hasil belajar siswa. Karena peran manjemen kesiswaan pengelolaan siswa dari awal pendaftaran, proses belajar sampai dengan kelulusan. Manajemen kesiswaan juga memiliki pengaruh terhadap keberhasilan belajar siswa sebab proses belajar mengajar lebih terarah yang mana menghasilkan siswa yang berpretasi. Keberhasilan siswa dalam belajar sudah menjadi tanggung jawab sekolah. Tetapi apabila pelaksanaan manajemen kesiswaan sudah bagus dilaksanakan tanpa adanya bimbingan atau perhatian dari orang tua sama saja tujuan yang diinginkan tidak dapat sepenuhnya tercapai, maka diharapkan semua dapat membantu pencapaian keberhasilan siswa dalam belajar.
\end{abstract}

(C) 2021 The Authors. Published by IICET.

This is an open access article under the CC BY-NC-SA license (https://creativecommons.org/licenses/by-nc-sa/4.0

\section{Corresponding Author:}

Mutia Putri

Universitas Negeri Padang

Email: mutiaputi1996@gmail.com

\section{Pendahuluan}

Hasil belajar merupakan kemampuan yang diperoleh individu setelah proses belajar berlangsung, yang dapat memberikan perubahan tingkah laku baik pengetahuan, pemahaman, sikap dan keterampilan siswa sehingga menjadi lebih baik dari sebelumnya. Hasil belajar adalah suatu proses aktivitas mental seseorang dalam berinteraksi dengan lingkungannya sehingga menghasilkan perubahan tingkah laku yang bersifat positif baik perubahan dalam aspek pengetahuan, sikap, maupun psikomotor (Sjukur, 2012). Dikatakan positif, oleh karena perubahan perilaku itu bersifat adanya penambahan dari perilaku sebelumnya yang cenderung menetap (tahan lama dan tidak mudah dilupakan). Belajar adalah proses perubahan melalui kegiatan atau prosedur latihan baik latihan di dalam laboratorium maupun dalam lingkungan alamiah. Salah satu kebijaksanaan sekolah yang dapat dipengaruhi oleh hasil belajar siswa adalah manajemen kesiswaan (Chotimah, 2020). Pada manajemen kesiswaan khususnya yang berkaitan dengan penentuan bentuk dari bimbingan siswa dalam belajar. Ada beberapa faktor ekstern yang berpengaruh terhadap belajar dapat dikelompokan menjadi 3 faktor, yaitu; faktor keluarga, faktor lingkungan masyarakat dan faktor sekolah. Artinya disiplin belajar siswa akan dapat memberikan kontribusi terhadap prestasi belajar siswa dengan didukung pula oleh manajemen kesiswaan yang dilakukan secara teratur (Firmanto, 2017).

Dalam upaya memperoleh hasil belajar yang tinggi, berbagai pihak telah mengupayakan usaha-usaha yang sekiranya dapat meningkatkan hasil belajar siswa Pihak sekolah yang berhubungan langsung dengan proses belajar mengajar telah berusaha meningkatkan efisiensi dan efektifitas proses belajar mengajar yaitu dengan 
meningkatkan kemampuan akademis guru. Kemampuan manajerial, kemampuan mengajar serta kemampuan melakukan interaksi dengan siswa dapat meningkatkan pencapaian tujuan belajar. Pihak sekolah juga telah meningkatkan sarana dan prasarana bagi siswa, peningkatan kemandirian belajar serta kemampuan siswa dalam penyesuaian diri di sekolah. Namun demikian hasil belajar siswa masih secara umum relative rendah.

Pada penelitian ini ada kesamaan dan perbedaan dengan hasil penelitian yang dilakukan Siti Chotimah yang berjudul "Manajemen Kesiswaan Terhadap Hasil Belajar Siswa SMK Swasta Yogyakarta". Perbedaan dalam penelitian ini adalah menitik beratkan kepada siswanya, seperti kegiatan mengajar, kemandian dan penyesuaian diri. Sedangkan dalam peneitian ini adalah menitik beratkan kepada manajemen kesiswaannya. Untuk kesamaan antara kedua penelitian ini adalah sama-sama membahas manajemen kesiswaan terhadap hasil belajar siswa. Kemudian, temuan penting dalam penelitian ini adalah kemampuan manajemen kesiswaan yang baik akan berdampak positif pada hasil belajar siswa, karena nantinya manajemen kesiswaan ini bertujuan untuk mengatur kegiatan dalam bidang kesiswaan agar proses pembelajaran yang dilakukan disekolah dapat berjalan dengan tertip dan teratur.

\section{Metode}

Penelitian ini menggunakan metode kajian pustaka. Artikel yang di-review pada penelitian ini merupakan artikel terbitan 5 (lima) tahun terakhir dan terakreditasi Sinta. Artikel yang di-review berjumlah 6 (enam) artikel yang yang mengulas tentang manajemen kesiswaan terhadap hasil belajar siswa. Artikel-artikel tersebut di-review dengan menggunakan matrik sintesis. Dengan adanya matrik sintesis peneliti dapat mengelompokkan argumen-argumen berbeda dari beberapa artikel, nantinya dari proses ini dapat ditarik kesimpulan artikel secara umum. Pada penelitian kali ini, topik yang dibahas oleh peneliti adalah tentang manajemen kesiswaan terhadap hasil belajar siswa.

\section{Hasil dan Pembahasan}

\section{Pengertian Manajemen Kesiswaan}

Manajemen kesiswaan atau pengelolaan peserta didik adalah suatu cara mengatur seluruh siswa mulai dari masuk sampai mereka lulus (Imron, 2011). Manajemen kesiswaan merujuk kepada kegiatan pencatatan siswa sejak dari awal diterima, kemudian diberikan pembinaan dan berakhir pada terselesaikannya proses pembelajaran serta menjadi alumni setelah selesai melaksanakan pembelajaran (Prihatin,2011). Dengan demikian, manajemen kesiswaan adalah suatu cara pengaturan peserta didik, mulai dari input, proses, output, dan menjadi outcome dari satuan pendidikan.

Adapun tujuan dan fungsi manajemen kesiswaan adalah: (1) meningkatkan pengetahuan, keterampilan, dan psikomotorik siswa; (2) mendidik dan membina kemampuan, bakat, dan minat; dan (3) mencapai kebahagiaan kesejahteraan hidup, belajar dengan baik, dan tercapai cita-citanya ( Imron. A \& Burhanudin, 2003). Tujuan pengelolaan kesiswaan yakni mengelola aktivitas kesiswaan untuk membantu kegiatan belajar sehingga sesuai, disiplin dan sesuai prosedur, serta dapat memberi masukan dalam mencapai sasaran yang sudah disepakati. Fungsi umum pengelolaan kesiswaan yakni sarana bagi siswa untuk mengembangkan diri secara individualitas, sosial, kebutuhan, maupun potensi-potensi peserta didik. Fungsi pengelolaan kesiswaan secara khusus, yaitu: (1) pengembangan individualitas, yakni agar siswa mampu mengembangkan potensi individualitasnya; (2) pengembangan sosial siswa, yakni supaya siswa mampu melakukan sosialisasi dengan masyarakatnya; (3) penyaluran aspirasi dan harapan siswa, yakni supaya terefleksikan kesenangan, dan minat siswa; dan (4) pemenuhan dan kesejahteraan siswa, yakni supaya siswa tentram dalam menjalankan pendidikannya. Fungsi pengelolaan kesiswaan yakni untuk sarana mengembangkan diri.

\section{Hasil Belajar}

Hasil belajar dapat didefinisikan sebagai sesuatu yang dapat dilakukan siswa yang sebelumnya tidak dapat mereka lakukan (Waston, 2002), sebagai cerminan dari kompetensi siswa (Nurhasan, 2016). Hasil belajar adalah pola- pola perbuatan, nilai-nilai, pengertian-pengertian, sikap-sikap, apresiasi, dan keterampilan, sebagai hasil interaksi dalam pembelajaran.Hasil pembelajaran dapat dijadikan tolak ukur untuk mengidentifikasi dan mengevaluasi tujuan pembelajaran (Aziz, 2012). Sebagai salah satu patokan untuk mengukur keberhasilan proses pembelajaran, hasil belajar merefleksikan hasil dari proses pembelajaran yang menunjukkan sejauh mana murid, guru, proses pembelajaran, dan lembaga pendidikan telah mencapai tujuan pendidikan yang telah ditentukan. Hasil belajar juga merupakan laporan mengenai apa yang telah diperoleh siswa dalam proses pembelajaran.

Dapat disimpulkan hasil belajar merupakan kompetensi dan keterampilan yang dimiliki siswa yang diperoleh melalui proses pembelajaran. Merujuk pada Taksonomi Bloom hasil belajar dalam rangka studi 
dicapai melalui tiga ranah, yaitu kognitif, afektif, psikomotor (Sudjana, 2019). Ranah kognitif, berkaitan dengan hasil belajar intelektual yang terdiri atas 6 aspek yaitu pengetahuan, pemahaman, penerapan, analisis, sintesis, dan penilaian. Ranah afektif, berkaitan dengan sikap dan nilai. Ranah afektif meliputi lima jenjang kemampuan yaitu menerima, menjawab, atau reaksi, menilai, organisasi dan karakterisasi dengan suatu nilai atau kompleks nilai. Ranah psikomotor meliputi keterampilan motorik, manipulasi benda-benda, koordinasi neuromuscular (menghubungkan, mengamati).

\section{Prinsip-prinsip Manajemen Kesiswaan}

Prinsip adalah sesuatu yang harus dipedomani dalam melaksanakan tugas. prinsip manajemen siswa mengandung arti bahwa dalam rangka mengelola siswa, prinsip-prinsip yang disebutkan dibawah ini haruslah selalu dipegang dan dipedomani. Adapun prinsip-prinsip manajemen kesiswaan adalah sebagai berikut: (a) Manajemen kesiswaan dipandang sebagai bagian dari keseluruhan manajemen sekolah. Oleh karena itu, ia harus mempunyai tujuan yang sama atau mendukung terhadap tujuan manajemen secara keseluruhan. ambisi sektoral manajemen kesiswaan tetap ditempatkan dalam kerangka manajemen sekolah. Ia tidak boleh ditempatkan diluar sistem manajemen sekolah. (b). Segala bentuk kegiatan manajemen kesiswaan harus lah mengembangkan misi pendidikan dan dalam rangka mendidik para siswa. Segala bentuk kegiatan, baik itu ringan, berat,disukai atau tidak disukai oleh siswa, haruslah diarahkan untuk mendidik siswa dan bukan untuk yang lainya. (c). Kegiatan-kegiatan manajemen kesiswaan haruslah diupayakan untuk mempersatukan siswa yang mempunyai aneka ragam latar belakang dan punya banyak perbedaan. perbedaan-perbedaan yang ada pada siswa, tidak diarahkan bagi munculnya konflik di antara mereka melainkan justru mempersatukan dan saling memahami dan menghargai. (d). Kegiatan manajemen kesiswaan haruslah dipandang sebagai upaya pengaturan terhadap pembimbing siswa. oleh karena membimbing, haruslah terdapat ketersediaan dari pihak yang dibimbing. ialah siswa sendiri. Tidak mungkin pembimbingan demikian akan terlaksana dengan dengan baik manakalah terdapat keengganan dari siswa. (e). Kegiatan manajemen siswa haruslah mendorong dan memacu kemandirian siswa. Prinsip kemandirian demikian akan bermanfaat bagi siswa tidak hanya ketika disekolah, melainkan juga ketika sudah terjun ke masyarakat. Ini mengandung arti bahwa ketergantungan siswa haruslah sedikit demi sedikit dihilangkan melalui kegitan-kegiatan manajemen kesiswaan. (f). Apa yang diberikan kepada siswa dan yang selalu diupayakan oleh kegiatan manajemen siswa harus lah fungsional bagi kehidupan siswa baik di sekolah lebih-lebih dimasa depan.

\section{Ruang Lingkup Manajemen Kesiswaan}

Kegiatan administrasi siswa dapat didaftar melalui gambaran bahwa lembaga pendidikan diumpamakan sebuah transformasi, yang mengenal masukan (input). Pengelolaan didalam tranformasi (proses) dan keluaran (output). Dengan demikian penyajian penjelasaan administrasi siswa dapat diurutkan menurut aspek-aspek tersebut. Dengan melihat pada proses memasuki sekolah sampai murid meninggalkannya, terdapat beberapa kelompok pengadministrasian yaitu: pencatatan prestasi belajar, pencatatan bimbingan dan penyuluhan serta, monitoring (Suharsimi,2008).

\section{Pendataan Kemajuan Belajar Siswa}

Keberhasilan kemajuan dan prestasi belajar para siswa memerlukan data yang otentik, dapat dipercaya dan memiliki keabsahan. Data ini diperlukan untuk mengetahui dan mengontrol keberhasilan atau prestasi oleh kepala sekolah sebagai manajer pendidikan di sekolah. Kemajuan belajar siswa secara periodik harus dilaporkan kepada orang tua sebagai masukan untuk berprestasi dalam proses pendidikan dan membimbing anaknya dalam belajar baik di rumah maupun di sekolah (E. Mulyasa, 2007).

Dalam pendataan kemajuan belajar siswa untuk kemajuan dan keberhasilan kegiatan belajar mengajar secara maksimal diperlukan buku catatan prestasi belajar murid, yang meliputi buku daftar nilai, buku legger dan raport. 1) Buku Daftar Nilai, merupakan buku pertama yang digunakan untuk menestan nilai hasil belajar yang di peroleh langsung dari kertas pekerjaan ulangan atau dari hasil ujian lisan. 2) Buku Legger, yaitu buku kumpulan nilai yang memuat semua nilai untuk semua bidang studi yang diikuti oleh siswa di dalam periode tertentu. Buku legger ini diisi oleh wali kelas yang menampung nilai-nilai dari guru-guru yang memegang pelajaran di kelas tersebut. Sekolah juga memiliki buku legger yang merupakan kumpulan nilai dari leggerlegger kelas. 3) Buku Raport, yaitu sebuah buku yang memuat hasil belajar siswa selama siswa tersebut mengikuti pelajan di suatu sekolah (Suharsimi,). Oleh karena itu paling sedikit banyaknya lembaran raport sama dengan banyaknya tingkatan di suatu sekolah.

Tujuan atau Fungsi Penilaian dari beberapa buku penting di atas, antara lain: 1). Penilaian Berfungsi Selektif, dengan cara mengadakan Penilaian, guru mempunyai cara untuk mengadakan seleksi atau penilaian terhadap siswanya. Penilaian itu sendiri mempunyai berbagai tujuan antara lain : a). untuk memilih atau menentukan siswa yang dapat naik kelas atau tingkat berikutnya. b). untuk memilih siswa yang seharusnya mendapat beasiswa. c). untuk memilih siswa yang berhak meninggalkan sekolah dan lain sebagainya. 2). Penilaian Bersifat Diagnosis Apabila alat yang di gunakan untuk melakukan penilaian cukup memenuhi 
persyaratan, maka dengan melihat hasilnya guru akan mengetahui kelemahan siswa. Disamping itu diketahui pula sebab-sebab kelemahan itu. Jadi dengan mengadakan penilaian sebenarnya guru mengadakan diagnosa kepada siswa tentang kebaikan dan kelemahannya. Dengan diketahui sebab-sebab kelemahannya akan lebih mudah dicari cara mengatasinya. 3). Penilaian Berfungsi Sebagai Pengukur Keberhasilan Fungsi dari penilaian ini dimaksudkan untuk mengetahui sejauh mana suatu program berhasil diterapkan. Keberhasilan program ditentukan oleh beberapa faktor, salah satunya yaitu sistem administrasi. Menurut Siagin, 2000 untuk mempermudah jalannya peninjauan gerak langkah maju mundurnya proses belajar mengajar pada suatu lembaga pendidikan maka, perlu adanya evaluasi hasil belajar yang dibukukan melalui buku nilai, buku legger dan raport siswa. Karena buku tersebut sangat diperlukan untuk melengkapi proses adminisrasi sekolah dalam rangka mencapai tujuan pendidikan, tujuan dari beberapa buku penting tersebut antara lain: (a) Untuk mengetahui derajat penguasaan materi (b) Untuk dapat menentukan tindakan perbaikan yang akan diambil (c) Untuk menentukan penempatan siswa dalam pengelompokan mata pelajaran (d) Untuk menentukan prestasi siswa. Untuk memacu prestasi siswa, maka kepada tiap-tiap guru diharuskan segera memeriksa, menilai dan mengembalikan tugas- tugas yang dibebankan kepada siswanya.

\section{Bimbingan dan Pembinaan}

Disiplin Siswa Bimbingan adalah proses untuk membantu individu di dalam membuat keputusan hidup yang positif, hal ini diperlukan di rumah, sekolah, dan di lingkungan sosial serta di setiap individu berada. Secara khusus layanan bimbingan bertujuan untuk membantu siswa agar dapat tercapai tujuan-tujuan perkembangan meliputi aspek pribadi, sosial, belajar dan karir bimbingan pribadi; sosial dalam mewujudkan pribadi yang taqwa, mandiri dan bertanggung jawab. Personel pelaksana pelayanan bimbingan adalah segenap unsur yang terkait di dalam program pelayanan bimbingan dengan koordinator dari guru pembimbing konselor sebagai pelaksana. Secara umum, bimbingan yang diberikan pihak sekolah terhadap siswa berkaitan dengan hal-hal sebagai berikut: (1)Pilihan bidang studi, (2)Penyesuaian kepada situasi sekolah, (3) Kesukaran belajar, (4)Kesukaran yang bertalian dengan keluarga dan lingkungan, (5)Gagal dalam bidang studi tertentu, (6)Kebutuhan dan kesempatan rekreasi, (7)Kurang minat terhadap bidang studi tertentu, (8) Kurang harga diri, (9) Hambatan-hambatan fisik, mental, emosi dan penyesuaian murid, (10) Pilihan pekerjaan penyesuaian waktu senggang, (11) Pertentangan antara ambisi dan kesanggupan siswa. Selain Bimbingan, Manajemen Kesiswaan juga melakukan pembinaan disiplin siswa. Konsep disiplin berkaitan dengan tata tertib, aturan, atau norma dalam kehidupan bersama yang melibatkan orang banyak. Disiplin merupakan kepatuhan kepada peraturan tata tertib, aturan, atau norma, dan lain sebagainya Menurut asal-usul kata disiplin berasal dari kata "discipline" yakni seorang yang belajar dari satu secara sukarela mengikuti seorang pemimpin. Orang tua dan guru merupakan pimpinan dan anak merupakan murid yang belajar dari mereka cara hidup yang menuju ke hidup yang berguna dan bahagia. Disiplin sekolah ialah usaha sekolah untuk memelihara perilaku siswa agar tidak menyimpang dan dapat mendorong siswa untuk dapat berprilaku sesuai dengan norma, peraturan, dan tata tertib yang berlaku di sekolah. Disiplin siswa dimaksudkan untuk mengarahkan siswa agar tumbuh dan berkembang sesuai kapasitas dan kemapuan bakat dan minat serta menjadi pribadi yang utuh sebagai makhluk individu dan sosial, cerdas, terampil dan bermoral. Jadi kedisplinan siswa adalah sikap seorang murid yang patuh atau tunduk terhadap peraturan yang ada di lingkungan (sekolah). Jadi kedisplinan siswa adalah kepatuhan dan ketaatan terhadap berbagai aturan dan tata tertib yang berlaku di sekolah.

\section{Monitoring}

Monitoring adalah suatu proses pemantauan untuk mendapatkan informasi tentang pelaksanaan suatu kegiatan yakni manajemen kesiswaan. Kegiatan monitoring adalah suatu kegiatan memonitor atau mengawasi seluruh aktivitas yang dilakukan oleh seluruh warga sekolah; dalam hal ini difokuskan pada aktivitas-aktivitas yang dilakukan oleh siswa (Hasbullah, 2006). Kegiatan monitoring ini dapat dilakukan secara langsung pada kegiatan yang di lakukan oleh siswa dan kegiatan monitoring secara tidak langsung dengan mendengarkan laporan dari orang yang terlibat dalam kegiatan.

\section{Majemen Kesiswaan Terhadap Hasil Belajar Siswa}

Peserta didik merupakan komponen yang sangat berpengaruh terhadap semua hal yang berkaitan dengan Sekolah. Salah satunya, peserta didik akan berpengaruh terhadap eksisensi sebuah sekolah. Biasanya, Sekolah yang peserta didiknya tergolong banyak maka pandangan masyarakat terhadap Sekolah itu sangat positif, dan sebaliknya jika sebuah Sekolah jumlah peserta didiknya sangat minim, maka sekolah tersebut akan di pandang negatif oleh masyarakat. Hal ini dapat di lihat dari segi hasil yang di ciptakan oleh siswa-siswa tersebut. Hal ini di buktikan dengan banyaknya orang tua yang memasukkkan anak-anaknya ke sekolah yang telah banyak mencetak hasil belajar yang bagus, baik hasil belajar di bidang akademik, maupun non akademik. Hal tersebut dimaksudkan agar anak-anak mereka juga berhasil mencetak prestasi, setidaknya dalam hal meningkatkan kemampuan belajarnya. 
Manajemen kesiswaan merupakan salah satu bidang operasional dalam pengelolaan sekolah. Manajemen kesiswaan adalah penataan dan pengaturan terhadap kegitan yang berkaitan dengan peserta didik mulai masuk sampai dengan keluarnya peserta didik tersebut dari suatu sekolah (Sulistyorini, 2009). Manajemen kesiswaan bukan hanya berbentuk pencatatan peserta didik melainkan meliputi aspek yang lebih luas secara operasional dapat membantu upaya pertumbuhan dan perkembangan peserta didik di sekolah. Salah satu yang menjadi fokus manajemen kesiswaan adalah bagaimana siswa bisa mengembangkan bakat dan minatnya agar nantinya akan berdampak pada hasil belajar siswa sehingga dapat mencetak prestasi.

Manajemen peserta didik tidak semata pencatatan data peserta didik akan tetapi meliputi aspek yang lebih luas yaitu dapat membantu upaya pertumbuhan anak melalui proses pendidikan di sekolah. Menurut Badrudin, 2014, Secara khusus, manajemen peserta didik bertujuan untuk : a. Meningkatkan pengetahuan, keterampilan, dan psikomotor peserta didik Menyalurkan dan mengembangkan kemampuan umum (kecerdasan), bakat, dan minat peserta didik. b. Menyalurkan aspirasi, harapan, dan memenuhi kebutuhan peserta didik . c. Peserta didik mencapai kebahagiaan dan kesejahteraan hidup yang lebih lanjut dapat belajar dengan baik dan mencapai cita-citanya

\section{Peran Manajemen Kesiswaan Terhadap Hasil Belajar}

Peran guru sangat penting, dari mulai perencanaan sampai kelulusan atau alumni. Di antara peran guru yaitu: (1) Pengelola, baik di dalam kelas atau di luar kelas. Guru memikirkan peserta didik dari awal hingga peserta didik lulus; (2) Guru selalu memberikan informasi mengenai segala sesuatu yang diperlukan peserta didik baik di dalam kelas, maupun di luar kelas; (3) Guru memberikan semangat kepada para peserta didik dengan membimbing dan pembinaan; (4) Memberikan kebutuhan para peserta didik; (5) Guru memberikan pembelajaran dan model yang baik bagi peserta didik; (6) Guru memberikan pembinaan untuk mengembangkan bakat dana minat peserta didik; (7) Guru memberikan bantuan untuk dapat mengevaluasi dan menilai peserta didik; (8) Guru memberikan bantuan untuk memperbaiki dan menilai proses pembelajarannya; (9) Dalam kegiatan belajar mengajar, guru selalu memberikan media yang menarik dalam pembelajaran; (10) Guru memberikan materi yang dibutuhkan peserta didik; (11) Memberikan kemudahan dan bantuan atas permasalahan peserta didik; dan (12) Memberikan penilaian baik dan buruk kepada peserta didik (Aliyyah, 2019). Peran manajemen kesiswaan terhadap peningkatan prestasi belajar adalah keterlibatan usaha pengaturan terhadap siswa mulai dari siswa tersebut masuk sekolah sampai mereka lulus terhadap hasil dari suatu kegiatan yang telah dikerjakan oleh siswa (Dwi Asih, 2021).

Manajemen kesiswaan termasuk berperan salah satu substansi manajemen pendidikan, maka manajemen kesiswaan (Firmanto, 2017) menduduki posisi strategis, , karena layanan sentral pendidikan baik dalam latar institusi persekolahan maupun yang berada di luar institusi persekolahan, tertuju pada peserta didik. Semua kegiatan pendidikan baik yang berkenaan dengan manajemen akademik, layanan pendukung akademik, sumber daya manusia, sumber daya keuangan, sarana prasarana, dan hubungan sekolah dengan masyarakat, senantiasa diupayakan agar peserta didik mendapatkan layanan pendidikan yang andal, baik, dan bermutu.

\section{Pengaruh Manajemen Kesiswaan Terhadap Hasil Belajar}

Manajemen kesiswaan memiliki pengaruh langsung dan tidak langsung secara positif dan signifikan terhadap prestasi belajar siswa. Hasil Pengujian yang dilakukan oleh Firmanto "Pengaruh Manajemen kesiswaan dalam mewujudkan prestasi siswa" menjelaskan bahwa secara kualifikasi gambaran hubungan menajemen kesiswaan memiliki hubungan yang kuat artinya keberhasilan belajar siswa harus didukung dan dipertahanan oleh manajemen kesiswaan, sehingga dapat mencapai prestasi belajar siswa secara langsung ataupun tidak langsung. Keberhasilan penyelenggaraan lembaga pendidikan (sekolah), akan sangat tergantung pada manajemen kesiswaan, karena manajemen kesiswaan ini akan memberikan kontribusi yang tinggi dan memberikan dukungan yang kuat terhadap komponen-komponen lain di dalam pencapaian tujuan sekolah, artinya baik buruknya manajemen kesiswaan, baik secara langsung ataupun tidak langsung akan mempengaruhi terhadap hasil belajar siswa (Nasihin, 2011).

Manajemen Kesiswaan sangat berpengaruh tehadap layanan yang mana pemusatan perhatian pada pengaturan dan pengawasan siswa di kelas dan luar kelas. Seperti: pengenalan, pendaftaran, layanan individual seperti penggembangan keseluruhan kemampuan, minat, kebutuhan sampai ia matang di sekolah. Lebih lanjut, proses pembelajaran di lembaga tersebut (sekolah) dapat berjalan lancar, tertib, dan teratur sehingga dapat memberikan kontribusi bagi pencapaian tujuan sekolah dan tujuan pendidikan secara keseluruhan (Nurmadiah, 2016). 


\section{Simpulan}

Hasil pembahasan menunjukan bahwa manajemen kesiswaan dapat memberi pengaruh positif terhadap hasil belajar siswa. Peran manajemen kesiswaan berkenaan dengan manajemen akademik, layanan pendukung akademik, sumber daya manusia, sumber daya keuangan, sarana prasarana, dan hubungan sekolah dengan masyarakat. Apabila Sekolah memiliki banyak peminat atau banyak peserta didik, maka nilai sekolah tersebut akan naik, begitu juga sebaliknya. Manajemen kesiswaan sangat berpengaruh baik itu didalm dan diluar sekolah, seperti pembelajaran, sarana prasana, dan kegiatan lomba yang diadakan baik diluar sekolah. Dalam penelitian dimasa mendatang bisa lebih memperdalam tentang manajemen kesiswaan terhadap hasil belajar siswa atau mungkin penelitian selanjutnya bisa menganalisis sarana dan prasana terhadap keberhasilan belajar siswa. Keberhasilan siswa dalam belajar sudah menjadi tanggung jawab sekolah. Tetapi apabila pelaksanaan manajemen kesiswaan sudah bagus dilaksanakan tanpa ada bimbingan atau perhatian dari orang tua sama saja tujuan yang diinginkan tidak dapat sepenuhnya tercapai. Diharapkan semua dapat membantu pencapaian keberhasilan dalam belajar.

\section{Referensi}

Aliyyah, R. R., Widyasari, W., Mulyadi, D., Ikhwan, S., \& Prananosa, A. G. (2019). Manajemen Kesiswaan Pada Sekolah Dasar. DIDAKTIKA TAUHIDI: Jurnal Pendidikan Guru Sekolah Dasar, 6(1), 29. https://doi.org/10.30997/dt.v6i1.1355

Amin, Muhammad, Sandya Suci Larasati, and Irwan Fathurrochman. "Implementasi Manajemen Kesiswaan dalam Meningkatkan Prestasi Non Akademik di SMP Kreatif "Aisyiyah Rejang Lebong." Jurnal Literasiologi 1.1 (2018): 103-121.

Aziz, A. A., Yusof, K. M., \& Yatim, J. M. (2012). Evaluation on the Effectiveness of Learning Outcomes from Students' Perspectives. Procedia-Social and Behavioral Sciences, 56, 22-30.

Chotimah, Siti. "Manajemen Kesiswaan Terhadap Hasil Belajar Siswa SMK Swasta Yogyakarta." Media Manajemen Pendidikan 2.3 (2020): 339-348.

Dimyati, \& Mudjiono. (2006). Belajar \& Pembelajaran. Jakarta: Rineka Cipta

E.Mulyasa,Manajaemen berbasis sekolah konsep strategi, dan Implementasinya, Bandung: PT Remaja Rosdakarya, 2007

Firmanto, Rian Anugrah. "Pengaruh Manajemen Kesiswaan terhadap Disiplin Belajar dalam Mewujudkan Prestasi Belajar Siswa." Jurnal Pendidikan UNIGA 11.1 (2017): 1-8.

Imron, A., \& Burhanudin. (2003). Manajemen Peserta Didik. Malang: Universitas Negeri Malang.

Imron. (2011). Manajemen Peserta Didik Berbasis Sekolah. Jakarta: PT Bumi Aksara.

Kristiawan, M. (2017). Manajemen Pendidikan. Yogyakarta: Deepublish.

Kpolovie, P. J., Joe, A. I., \& Okoto, T. (2014). Academic achievement prediction: Role of interest in learning and attitude towards school. International Journal of Humanities Social Sciences and Education (IJHSSE), 1(11), 73-100.

Mary, Coulter. 2002. Manajemen. Jakarta: Prenhallindo.

Mølstad, C. E., \& Karseth, B. (2016). National curricula in Norway and Finland: The role of learning outcomes. European Educational Research Journal, 15(3), 329-344.

Nasihin, Sukarti dan Sururi. (2011). Administrasi Pendidikan Universitas Pendidikan Indonesia. Manajemen Pendidikan. Bandung: Alfabeta.

Nurhasanah, S., \& Sobandi, A. (2016). Minat Belajar Sebagai Determinan Hasil Belajar Siswa. Jurnal pendidikan manajemen perkantoran, 1(1), 135-142.

Nurmadiah, N. (2016). Konsep Manajemen Kesiswaan. Al-Afkar : Jurnal Keislaman \& Peradaban, 2(1). https://doi.org/10.28944/afkar.v2i1.88

OKTA MEGA PUSPITASARI, D. I. N. O., et al. Strategi Pembinaan Kompetensi Siswa Sebagai Persiapan Lomba Kompetensi Siswa (LKS) Bidang Computer Numerical Control (CNC) Jurusan Teknik Pemesinan SMKN 5 Surabaya. Inspirasi Manajemen Pendidikan, 2019, 7.1.

Popenici, S., \& Millar, V. (2015). Writing Learning Outcomes. A practical guide for academics. University of Melbourne, Australia.

Prihatin, E. (2011). Manajemen Peserta Didik. Bandung: Alfabeta

Purnomo, S. (2017). Program studi manajemen pendidikan islam pascasarjana institut agama islam negeri purwokerto 2017.

Suharsimi Arikunto, Manajemen Pendidikan, Yogyakarta: aditya Media, 2008

Sjukur, Sulihin B. "Pengaruh blended learning terhadap motivasi belajar dan hasil belajar siswa di tingkat SMK." Jurnal pendidikan vokasi 2.3 (2012). 
Watson, P. (2002). The role and integration of learning outcomes into the educational process. Active Learning in Higher Education, 3(3), 205-219.

Widayanti, L. (2014). Peningkatan Aktivitas Belajar dan Hasil Belajar Siswa dengan Metode Problem Based Learning pada Siswa Kelas VIIA MTs Negeri Donomulyo Kulon Progo Tahun Pelajaran 2012/2013. Jurnal Fisika Indonesia, 17(49). 